\title{
Genetic determinants of p53-induced apoptosis and growth arrest
}

\author{
Kornelia Polyak, ${ }^{1,2}$ Todd Waldman, ${ }^{2}$ Tong-Chuan He, ${ }^{1,2}$ Kenneth W. Kinzler, ${ }^{2,3}$ and \\ Bert Vogelstein ${ }^{1,2,3}$
}

${ }^{1}$ Howard Hughes Medical Institute, ${ }^{2}$ The Johns Hopkins Oncology Center, and ${ }^{3}$ The Program in Human Genetics and Molecular Biology, Johns Hopkins University, Baltimore, Maryland 21231 USA

\begin{abstract}
Previous studies have suggested that expression of p53 in cancer cells can result in either growth arrest or apoptosis. Accordingly, expression of p53 in a series of colorectal cancer cell lines yielded growth arrest in some lines (A-lines) and apoptosis in others (D-lines). To investigate the basis of this difference, we evaluated the role of $\mathbf{p 2 1}$ WAF1/Cip1, a known mediator of p53-induced growth arrest. Inactivation of $\mathbf{p} 21$ by homologous recombination converted an A-line to a D-line, suggesting that $\mathrm{p} 21$ could protect cells from apoptosis.

However, examination of p53-induced p21 expression in naturally occurring D-lines and A-lines demonstrated that the induction of $\mathrm{p} 21$ could not account for the differential response to $\mathrm{p53}$. Moreover, when a D-line was fused to an A-line, the resulting hybrid cells underwent apoptosis in response to $\mathrm{p} 53$, indicating that the apoptosis pathway was dominant over the growth arrest pathway. Therefore, the apoptotic response to $\mathrm{p} 53$ in colorectal cancer cells is modulated by at least two factors: p21-mediated growth arrest that can protect cells from apoptosis in A-cells, and trans-acting factors in D-cells that can overcome this protection, resulting in cell death.
\end{abstract}

[Key Words: p53; apoptosis; growth arrest; p21 WAF1/Cip1]

Received April 25, 1996; revised version accepted June 17, 1996.

The $p 53$ gene is mutated in a large fraction of cancers, suggesting that the expression of wild-type p53 is often rate-limiting for tumor growth (Baker et al. 1990; Hollstein et al. 1991). Two mechanisms to explain this growth inhibition have been described. First, p53 can arrest the growth of some cells by inhibiting progress directly through the cell cycle. This inhibition is at least in part mediated by transcriptional activation of $\mathrm{p} 21^{\text {WAF1/CIPl}}$, which binds to and inactivates the cyclindependent kinases required for cell cycle progression (ElDeiry et al. 1993; Harper et al. 1993; Xiong et al. 1993). Accordingly, homozygous deletion of $\mathrm{p} 21$ in mouse embryonic fibroblasts or in human colon cancer cells partially or completely abrogates the radiation-induced $\mathrm{G}_{1}$ arrest mediated by p53 (Brugarolas et al. 1995; Deng et al. 1995; Waldman et al. 1995). Second, p53 expression can stimulate apoptosis. This stimulation is consistent with the demonstration that the apoptotic response to radiation and other DNA-damaging agents is diminished in the absence of p53 (Clarke et al. 1993, 1994; Lowe et al. 1993; Merritt et al. 1994). Moreover, overexpression of p53 in certain cell types results in apoptosis (YonishRouach et al. 1991; Shaw et al. 1992).

The mechanism by which p53 stimulates apoptosis is largely unknown. Apoptosis does not require p21, as mouse cells without $p 21$ genes still undergo apoptosis following $\gamma$-irradiation (Brugarolas et al. 1995; Deng et al. 1995). Several genes linked to apoptosis including Bax and Fas/APO-1, are trans-activated following p53 expression in some cell types, but whether the apoptotic properties of $\mathrm{p} 53$ are dependent on its sequence-specific transcriptional activation properties is controversial Caelles et al. 1994; Haupt et al. 1995; Miyashita and Reed 1995; Owen-Schaub et al. 1995; Sabbatini et al. 1995).

It has been demonstrated previously that some cells arrest their growth in response to p53 expression, whereas others undergo apoptosis (Liu et al. 1994, 1995; Symonds et al. 1994; Yang et al. 1995). Moreover, varying the environment of a single cell type by, for example, removing growth factors from the medium, can affect the response to p53 (Yonish-Rouach et al. 1991; Canman et al. 1995; Lin and Benchimol 1995). Two "death regulator" proteins, Bcl-2 and Bax, are affected oppositely by $\mathrm{p} 53$ and an increased $\mathrm{Bax} / \mathrm{Bcl} 2$ ratio can make cells more susceptible to apoptosis under certain conditions (Oltvai and Korsmeyer 1994; Miyashita and Reed 1995). However, the biochemical and genetic determinants that dictate which of these two pathways-death or arrest-will be chosen by a particular cell following p53 expression remain largely obscure. We have begun to attempt to investigate this critical cellular decision using a genetic approach to study human colorectal cancer cell lines that either arrest or die following an identical p53 stimulus.

\section{Results}

The effect of p53 on cell proliferation

To examine the effect of exogenous wild-type p53 over- 
Polyak et al.

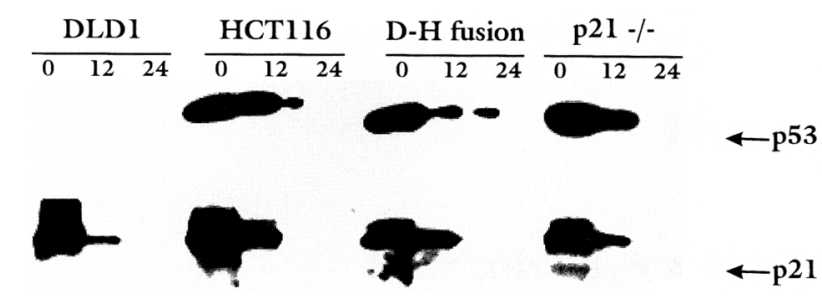

Figure 1. Expression of $\mathrm{p} 53$ and $\mathrm{p} 21$ proteins in various cell lines. Immunoblot analysis of p53 and p21 protein levels in DLD1, HCT116, D-H fusion, and HCT116 p21 - / - cells. Cells were harvested before $(0)$, or 12 and $24 \mathrm{hr}$ after infection with Ad-p53, as indicated. Equal amounts of protein were separated by electrophoresis and subjected to immunoblot analysis with p53- or p21-specific monoclonal antibodies. No p21 protein was detected in HCT116 p $21-/$ - cells and in DLD1 cells before infection with Ad-p53. The endogenous p53 protein in the uninfected cells is below the detection level at the exposure levels shown.

expression on the proliferation of colorectal carcinoma cells, cell lines were infected with a replication defective adenovirus containing a wild-type p53 cDNA expression cassette (Ad-p53). The relative efficiency of adenovirus infection was determined by X-gal staining of cells infected with a control adenovirus vector containing the bacterial lacZ gene in place of the $p 53$ gene (Ad-lacZ). In 12 of the 15 lines tested, $>80 \%$ of the cells could be infected at a multiplicity of 100:1.

The effect of wild-type p53 expression on these 12 lines was assessed by flow cytometry and microscopy following staining with the DNA-binding dye H33258. Ad-p53 infection resulted in apoptosis $>50 \%$ of the cells died) in six lines (here called D-lines), and in growth arrest $1>50 \%$ decrease of cells in $S$ phase in the absence of significant apoptosis) in three lines (called A-lines). The D-lines included DLD1, Caco2, Lim2405, LoVo, LS123, and R, and the A-lines included HCT116, SW480, and SW1417. In the three other lines (SW837, SKCO-1, and LS174T), p53 overexpression had little effect on the flow cytometric patterns.

These differences in response were not simply attributable to differences in p53 expression levels, as determined by immunoblot analysis of cell lysates prepared at various times after infection. Expression of p53 could be detected as early as $4 \mathrm{hr}$ after infection and peaked at 24-48 hr (Fig. 1). In cells not undergoing apoptosis, p53 expression continued at high levels for at least $96 \mathrm{hr}$. The maximum exogenous p53 levels were at least 10 times higher than the endogenous p53 levels. We found that the exogenous p53 protein levels were comparable in all the cell lines tested (examples in Fig. 1) and that the expressed p53 protein appeared to be fully functional isee below). Furthermore, unlike what has been observed in some previous studies, the status of endogenous p53 (wild-type or mutant) had no correlation with the cell line's response to p53 overexpression (Gomez-Manzano et al. 1996; Harris et al. 1996). For example, DLD1 cells underwent apoptosis, whereas SW480 cells growth-arrested following p53 overexpression, despite the fact that both lines have $p 53$ gene mutations.
DLDl

Figure 2. Cell cycle analysis following $\mathrm{Ad}-\mathrm{lac} Z$ and $\mathrm{Ad}-\mathrm{p} 53$ infection. Cells were harvested 24 or $48 \mathrm{hr}$ following infection with Ad-lacZ or Ad-p53 infection and analyzed by flow cytometry as described in Materials and methods. The Ad-lacZ-infected cells showed identical patterns at both time points, and therefore only one of the histograms is shown. The results shown are representative of three independent experiments.

\section{HCT116}
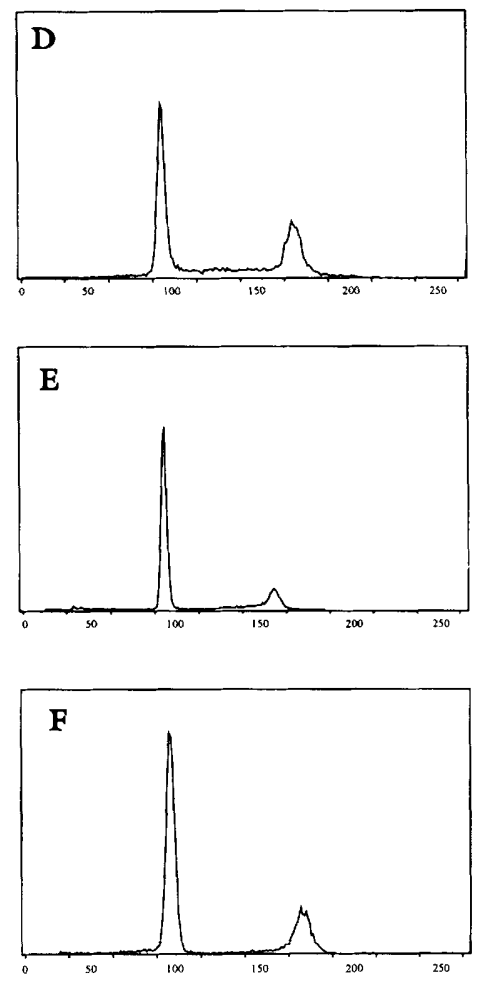

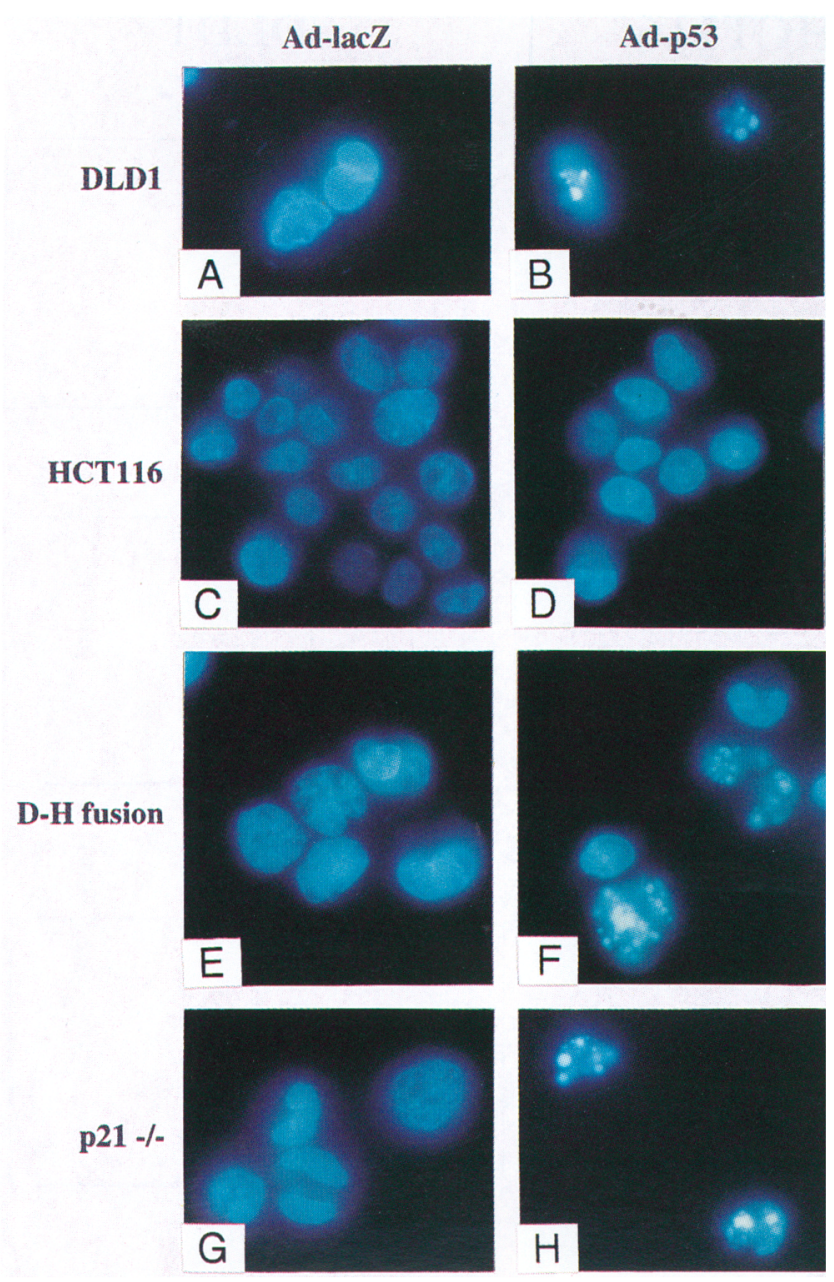

Figure 3. Microscopic analysis following Ad-p53 infection. Cultures of the indicated cell lines were harvested $48 \mathrm{hr}$ after infection with $\mathrm{Ad}-\mathrm{lacZ}$ or Ad-p53, fixed, and stained with the DNA-binding dye Hoechst 33258 and observed under fluorescence microscopy. Representative cells are shown.

Two cell lines that exhibited representative apoptotic or growth arrest responses were selected for further study. DLDl cells, a D-line, had mutant alleles of the p53 gene, whereas in HCT116 cells, an A-line, both alleles of the $p 53$ gene were wild type. Both lines were near-diploid, making them suitable for cell fusion studies. The DLD1 cell line initially underwent a growth arrest in response to p53, with virtually all cells blocked in $G_{1}$ or $G_{2}$ by $24 \mathrm{hr}$ after Ad-p53 infection (Fig. 2B). Apoptosis began shortly thereafter, with all cells dying by $48 \mathrm{hr}$ (Figs. 2C and 3B). HCT1 16 cells also arrested in $\mathrm{G}_{1}$ and $\mathrm{G}_{2}$ by $24 \mathrm{hr}$ after Ad-p53 infection (Fig. 2E). However, in striking contrast to DLD1 cells, HCT116 cells remained stably arrested for up to $72 \mathrm{hr}$ after infection, with no morphological or cytometric signs of apoptosis (examples in Figs. 2F and 3D). In extended experiments a small fraction of HCT116 cells died at later times (96$120 \mathrm{hr}$ following infection).
The role of $p 21$

p21 is a known mediator of the p53-induced growth arrest (El-Deiry et al. 1993; Brugarolas et al. 1995; Deng et al. 1995; Waldman et al. 1995). To test the relationship between p 21 and the growth arrest/apoptosis switch, we analyzed the effect of exogenous wild-type p53 overexpression on HCT116 cells with a homozygous deletion of the $p 21$ gene (p21 - - cells) (Waldman et al. 1995). As noted above, HCT116 cells underwent a stable cell cycle arrest $24 \mathrm{hr}$ after p53 overexpression. Both $G_{1}$ and $G_{2}$ phase blocks were observed, resulting in the near absence of $S$ phase (Fig. 2E). In contrast, the p21-/ - cells did not arrest after p53 overexpression, as indicated by the high proportion of S-phase cells present $24 \mathrm{hr}$ after infection (Fig. 4B). The absence of a $G_{1}$ block following Ad-p53 infection confirms and extends previous observations demonstrating that the induction of endogenous p 53 by DNA damage does not result in a $G_{1}$ block in human p21-/ - cells (Waldman et al. 1995, 1996). These results also indicate that overexpression of p53 can independently induce $\mathrm{a}_{2}$ block. Furthermore, this $\mathrm{G}_{2}$ block was dependent on $\mathrm{p} 21$, as demonstrated by the absence of $G_{2}$ cell accumulation in the p21-/- cells (Fig. 4B). Surprisingly, however, the absence of p21 resulted not only in the abrogation of the cell cycle blocks, but also in the subsequent apoptosis of these cells. At 24 $\mathrm{hr}$ following Ad-p53 infection, $\sim 15 \%$ of the p $21-/-$ cells had died, whereas at $48 \mathrm{hr}$, virtually $100 \%$ of the cells were dead (Fig. 4C). Microscopic analysis revealed typical features of apoptosis in the dead and dying p21-/- cells, whereas in cells infected with the control adenovirus (Ad-lacZ) no signs of apoptosis were observed (Fig. $3 \mathrm{G}, \mathrm{H})$. This response to p53 expression was indistinguishable in two independently isolated HCT116 p 21-/ - clones.

We next disrupted the $p 21$ genes in a D-line, DLD1, as described in Materials in methods. In the parental DLD1 cells, growth arrest was apparent $24 \mathrm{hr}$ after infection with Ad-p53 (Fig. 2B). This arrest was dependent on p21, as it was absent in the p21-/- cells (Fig. 4E). Both the parental and the p21- $/$ - DLD1 cells underwent apoptosis by $48 \mathrm{hr}$ after infection with $\mathrm{Ad}-\mathrm{p} 53$ (Figs. 2C and $4 F)$. Therefore, the DLD1 p21-/ - cells behaved very similarly to the HCT116 p21-/ - cells, though the responses of the parental lines were quite different. These results suggested that $\mathrm{p} 21$ activity might be important in determining whether a cell undergoes an A- or D-type response. Furthermore, the HCT116 p21 $/ /$ - cell line, heterozygous for a $\mathrm{p} 21$ deletion, displayed an intermediate response, with a block in some cells and apoptosis in others (data not shown). This latter result suggested that the intracellular concentration of p21 might significantly modulate the apoptosis/growth arrest decision point.

To evaluate further the role of $\mathrm{p} 21$ in these responses, we measured the levels of $\mathrm{p} 21$ before and after Ad-p 53 infection. The constitutive levels of $\mathrm{p} 21$ and $\mathrm{p} 53 \mathrm{did}$ not correlate with the A or D response, although they did correlate precisely with the presence or absence of wild- 
Figure 4. Cell cycle analysis of p21-deficient cells following p53 expression. Cells were harvested 24 and $48 \mathrm{hr}$ after $\mathrm{Ad}-\mathrm{lacZ}$ (only $48 \mathrm{hr}$ time point shown) and Ad-p53 infection and analyzed by flow cytometry.
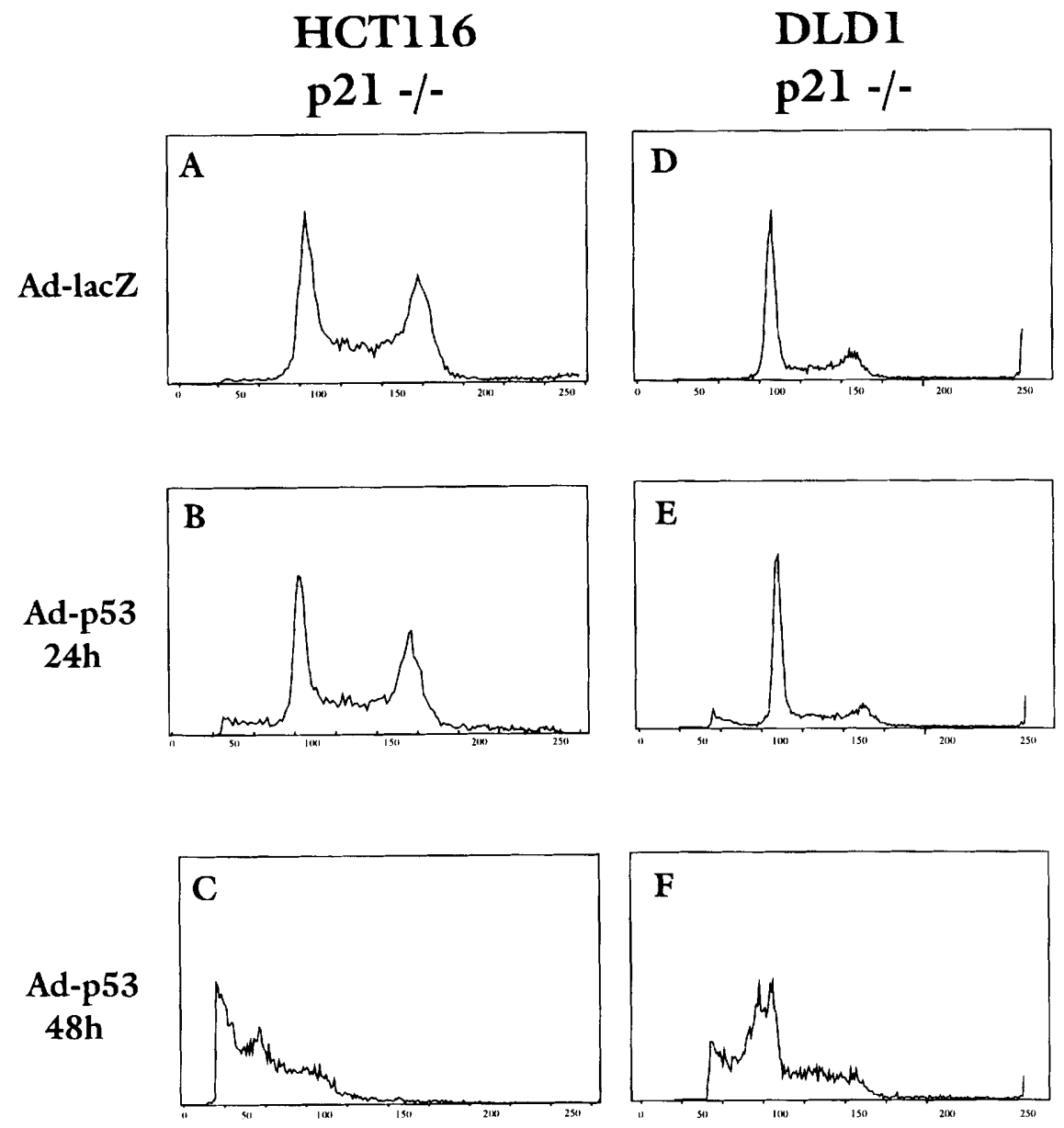

type $p 53$ genes. Cell lines with mutant p53 expressed little p21 in comparison to those with wild-type p53, consistent with previous studies and exemplified by the examples in Figure 1. Following DNA damage, the wildtype p53-containing cell lines exhibited a large increase in p21, whereas the mutant p53-containing lines exhibited little or no induction of $\mathrm{p} 21$, again consistent with previous studies (El-Deiry et al. 1994). Following Ad-p53 infection, however, all of the lines expressed comparable levels of p21 (examples in Fig. 1). Therefore, although the manipulation of p21 status could clearly affect the response to p53 (Fig. 4), differences in expression of p21 following Ad-p53 infection of unmanipulated cells could not account for the differences between A- and D-lines. This result also demonstrated that the exogenous p53 resulting from Ad-p53 infection was equivalently functional in all of the cell lines analyzed.

\section{Evidence for a dominant apoptosis-inducing factor}

The results recorded above suggested that some cellular factor other than $\mathrm{p} 21$ was responsible for the differences between A- and D-lines. To begin to explore the nature of this postulated factor, cell fusion experiments were performed. Drug-resistant clones of DLD1 and HCT116 cells were generated through transfection as described in Materials and methods. Pools containing at least 50 independent geneticin- or hygromycin-resistant clones were fused to create homofusions of D-lines (DLD1DLD1) or A-lines (HCT116-HCT116) or heterofusions (DLD1-HCT116). Pools of stable clones resistant to both drugs were analyzed by flow cytometry and determined to have a $G_{1}$ DNA content of $4 N$, documenting successful fusions. The adenovirus infectibility of the fusion lines was determined to be unaltered compared with the parental cells, as assessed with the Ad-lacZ virus. Similarly, the expressed p53 and the induced p21 protein levels were the same in the fusions as in the parental cells following Ad-p53 infection (Fig. 1).

The physiologic responses of the homofusions to p53 overexpression were the same as those observed in the parental cells. DLD1 homofusions underwent apoptosis and HCT116-HCT116 cells underwent a stable growth arrest (Fig. 5A-D). Interestingly, however, the DLD1HCT 116 heterofusions, after a transient growth arrest at $24 \mathrm{hr}$ following Ad-p53 infection, underwent a complete apoptosis by $48 \mathrm{hr}$ with kinetics and morphology identical to that observed in DLD1 cells (Figs. 5F and 3F). As each fusion population analyzed represented a pool including numerous individual clones, these results could 

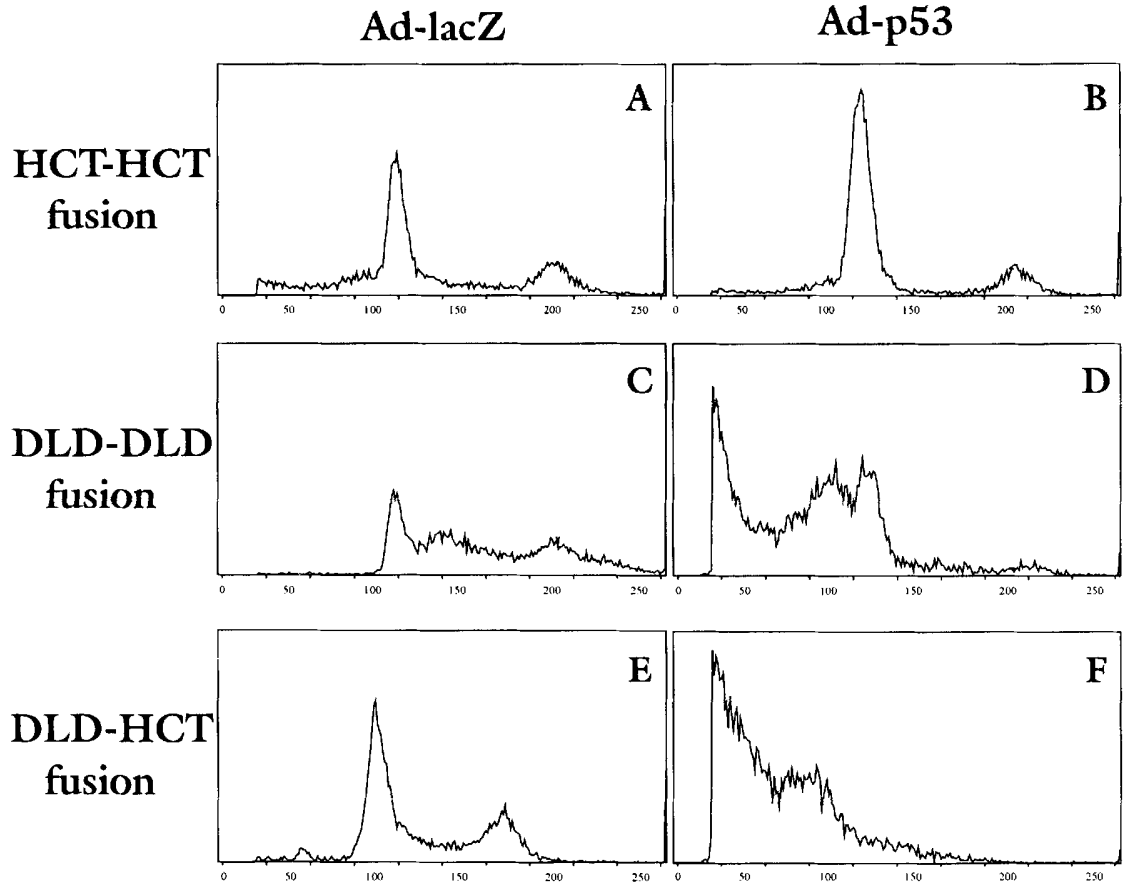

Figure 5. Cell cycle analysis of fusion cell lines following p53 expression. Cells infected with the indicated adenoviruses were collected $48 \mathrm{hr}$ after infection and analyzed by flow cytometry. The $\mathrm{G}_{1}$ DNA content of these cells was $\sim 4 \mathrm{~N}$, confirming that they were the product of cell fusions. not be explained by clonal heterogeneity. Therefore, the apoptotic pathway stimulated by wild-type p53 overexpression in DLD1 cells is dominant over the sustained growth arrest pathway observed in HCT116 cells.

Because the above experiments suggested the existence of a dominant apoptotic factor, we considered the possibility that bax, which had been shown previously to induce apoptosis in some cell types, might be differentially expressed in the various lines. Western blot analysis of cell lysates, however, revealed no significant differences in the expression of bax in the cell lines, before or after Ad-p53 infection. Both HCT116 and DLDl cells expressed slightly more Bax protein (less than twofold) following infection with Ad-p53 than uninfected or AdlacZ infected cells (Fig. 6A).

Finally, we evaluated the role of cysteine proteases in the A- and D-type responses. A family of cysteine proteases [interleukin converting enzyme (ICE)-like proteases/mammalian ced3 homologs] have been identified as general executors of apoptotic pathways (Kumar 1995; Takahashi and Earnshaw 1996). A synthetic peptide inhibitor specific for the ICE protease (Ac-YVAD-CMK) was unable to block p53-induced apoptosis in either DLD1 or HCT116 p21 - / - cells (data not shown). However, PARP [poly (ADP-ribose) polymerase], a known substrate for prICE/CPP32 (an ICE homolog) was found to be cleaved in all cell lines that underwent apoptosis in response to p53 overexpression (Fig. 6B) (Lazebnik et al. 1994; Tewari et al. 1995). The appearance of the $85-\mathrm{kD}$ fragment of PARP preceded morphological signs of apoptosis, and could be observed at 24-36 hr following Adp53 infection of lines undergoing apoptosis. No PARP cleavage was observed in HCT116 cells, even $48 \mathrm{hr}$ after infection, confirming that these cells did not enter the apoptotic pathway. Therefore, ICE-like proteases are ac- tivated following p53 expression if the cell undergoes apoptosis.

\section{Discussion}

Little is known about the apoptosis associated with p53, or about the controlling mechanisms that determine whether cells arrest or die following p53 overexpression. The studies described above lead to several important conclusions regarding the relationship among p53, p21, growth arrest, and apoptosis. First, in both D-lines and A-lines, the initial response to exogenous p53 is similar-a growth arrest, in both the $G_{1}$ and $G_{2}$ phases of the cell cycle, which is mediated by $\mathrm{p} 21$. This dependence on p21 was demonstrated rigorously by the results observed following genetic disruption of $\mathrm{p} 21$ in both DLD1 and HCT116 cells. Second, cancer cell lines of the same histological type can display quite different responses to p53 following this initial growth arrest. D-lines undergo a profound apoptosis, whereas A-lines remain stably arrested. Such differences are consistent with previous studies on breast cancer and brain tumor lines (Casey et al. 1991; Gomez-Manzano et al. 1996). Third, the apoptosis stimulated by $\mathrm{p} 53$ is associated with activation of ICE-like proteases similar to that documented in other apoptotic pathways (Kumar 1995; Takahashi and Earnshaw 1996). Fourth, the p21-mediated growth arrest can protect A-line cells from apoptosis. Deletion of p21 genes from the HCT116 cell genome led to a dramatic change in its response to p53, converting it from a virtually complete growth arrest to a striking apoptosis. This result demonstrates that $\mathrm{A}$-lines are not intrinsically deficient in the proteolytic or other enzymatic activities or activators responsible for carrying out programmed cell death, as these can be revealed when the 
cell cycle block promoted by $\mathrm{p} 21$ is released. Finally, it was demonstrated that the $\mathrm{p} 21$-mediated protection of apoptosis in A-lines can be overcome by factors present in D-lines. This conclusion is based on two experimental observations: (1) D-lines undergo apoptosis following expression with Ad-p53, despite the fact that p21 is induced and is able to block cell cycle progression to the same extent as in A-lines (Fig. 1); and (2) fusion of a D-line with an A-line resulted in cells that underwent apoptosis in response to $\mathrm{p} 53$, despite the fact that $\mathrm{p} 21$ induction was as substantial in the hybrid as in the parental lines.

In summary, at least two cell-specific factors seem to control the decision of the cell concerning which of the two pathways it will enter following expression of p53. A

\section{A}

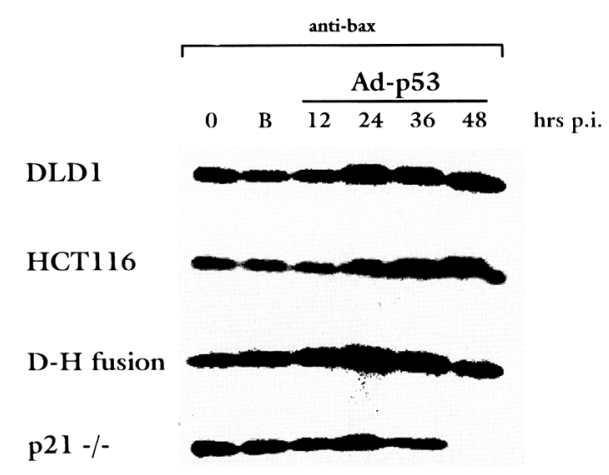

B

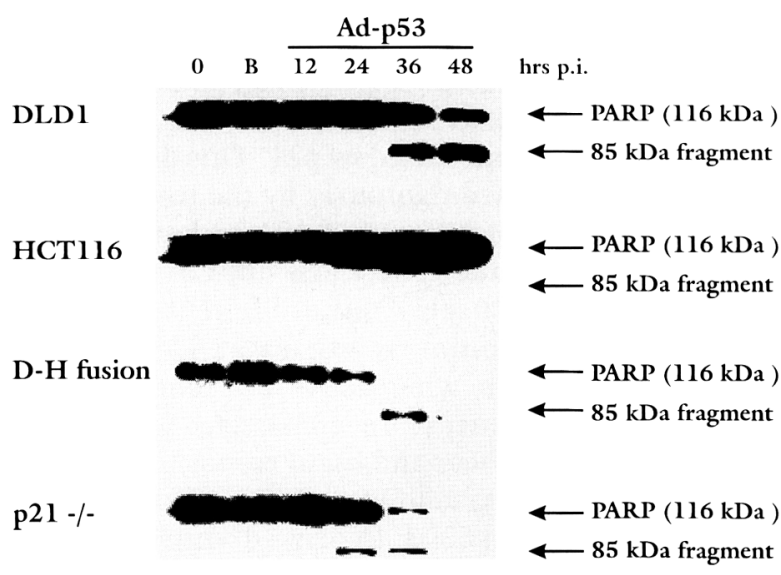

Figure 6. Immunoblot analysis of Bax and PARP proteins following infection with $\mathrm{Ad}-\mathrm{p} 53$. Cultures of the indicated cell lines were harvested before infection $(0), 24 \mathrm{hr}$ after infection with $\mathrm{Ad}-\operatorname{lac} Z(\mathrm{~B})$, and at various time points $(12-48 \mathrm{hr})$ following $\mathrm{Ad}-\mathrm{p} 53$ infection. Equal amounts of protein were loaded in each lane and immonoblot analysis was performed using baxspecific $(A)$ or PARP-specific $(B)$ monoclonal antibodies. The migrations of the PARP protein $(116 \mathrm{kD})$ and its proteolytic fragment $(85 \mathrm{kD})$ are indicated with arrows. In some of the cell lines, the PARP protein has been degraded completely by $48 \mathrm{hr}$ and no signal is detected.

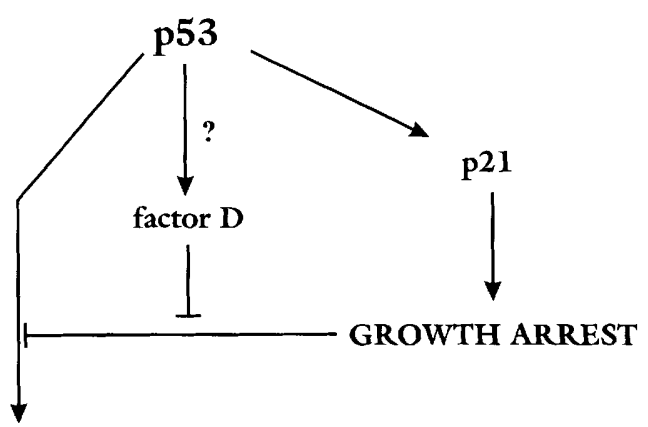

\section{APOPTOSIS}

Figure 7. Model connecting the p53-induced growth arrest and apoptotic pathways. There appears to be at least two microenvironmental factors, $\mathrm{p} 21$ and factor $\mathrm{D}$, that modulate the $\mathrm{p} 53$ induced apoptosis and growth arrest. A block to apoptosis by growth arrest can be overcome by factor $D$, which may be induced by p53. Cell death will occur in response to p53 (1) if the growth arrest pathway is eliminated, as in HCT116 cells following homozygous deletion of $\mathrm{p} 21$, or (2) in the presence of factor D, as in DLDl and D-H fusion cells, whether or not $\mathrm{p} 21$ is induced.

simple model to explain these results is presented in Figure 7 . One of these factors is clearly p2l, apparent from the experiments with HCT116 A-line cells and its p21-deficient derivatives. In A-cells, the p21-mediated growth arrest following p53 expression blocks the apoptotic pathway induced by p53. A similar protection against apoptosis has been observed following the nerve growth factor (NGF)-induced expression of $\mathrm{p} 21$ (Poluha et al. 1996). The second is an intracellular factor (factor $D$ ) found in D-lines that can overcome the p21 effect. This factor can clearly act in trans, as it is dominant in the hybrids. Cell death occurs either in the absence of growth arrest (p21-1- deficient A-cells) or in the presence of factor D (DLD1 and D-H fusion cells). These observations suggest that future experiments to identify factor $D$, using genetic or biochemical approaches, could substantially illuminate the p53-dependent apoptosis pathway.

\section{Materials and methods \\ Cell culture and transfections}

Cell lines used in the study were obtained from American Type Culture Collection (Rockville, MD) with the exceptions of $\mathrm{R}$ and LIM 2405, which were the generous gifts of M. Brattain (Medical College of Ohio, Toledo) and R. Whitehead (Ludwig Institute for Cancer Research, Royal Melbourne Hospital, Australia), respectively. All cell lines were maintained in McCoy's 5A medium (GIBCO-BRL, Bethesda, MD) supplemented with $10 \%$ fetal bovine serum (Hyclone, Logan, UT) and penicillin/ streptomycin (GIBCO-BRL). Both DLD1 and HCT116 cells contain full-length Rb protein (K. Polyak, K.W. Kinzler, B. Vogelstein, unpubl.). To generate stable drug-resistant clones of these lines, HCT116 and DLD1 cells were transfected at $\sim 70 \%$ confluence with $4 \mu \mathrm{g}$ of linearized plasmid DNA (pCEP4 or pTKNEO) using lipofectamine (GIBCO-BRL) following the manufacturer's protocol. HCT116 transfectants were selected 
in $0.1 \mathrm{mg} / \mathrm{ml}$ of hygromycin (Calbiochem, La Jolla, CA) or 0.4 $\mathrm{mg} / \mathrm{ml}$ of geneticin (GIBCO-BRL), and DLDl transfectants were selected in $0.25 \mathrm{mg} / \mathrm{ml}$ of hygromycin or $1 \mathrm{mg} / \mathrm{ml}$ of geneticin.

\section{Disruption of $\mathrm{p} 21$ genes}

The HCT116 p $21+/$ - and p21 - / - cell lines have been described previously (Waldman et al. 1995). To generate p21-deficient DLD1 cells, the same strategy was used, employing sequential homologous recombination with targeting vectors containing geneticin or hygromycin-resistance genes. Homologous recombination was less frequent in DLD1 cells than in HCT116 cells, with only 5 of 157 drug-resistant clones exhibiting a homologous recombinant of the first allele $(\mathrm{p} 21+/$ - cells $)$. In the second round of targeting, 1 of 135 doubly drug-resistant clones derived from the $\mathrm{p} 21+/$ - cells exhibited the desired recombinant (p21-/- cells). Homologous recombination was tested by Southern blotting and verified by the absence of $\mathrm{p} 21$ protein in Ad-p53 infected cells on Western blotting.

\section{Cell fusions}

Approximately $4 \times 10^{6}$ cells from drug-resistant pools of DLD1 and HCT 116 cells were combined in one $50-\mathrm{ml}$ conical tube and washed in $10 \mathrm{ml}$ of Dulbecco's modified Eagle medium (DMEM) (GIBCO-BRL). Cells were resuspended in $1 \mathrm{ml}$ of $50 \%$ PEG-1450 in DMEM and incubated at room temperature for $1 \mathrm{~min}$, followed by washing in $20 \mathrm{ml}$ of DMEM. Cells were incubated overnight in growth medium and drug selection started the following day. HCT116 homofusions were selected in $0.1 \mathrm{mg} / \mathrm{ml}$ of hygromycin plus $0.4 \mathrm{mg} / \mathrm{ml}$ of G418, whereas DLD1 homofusions and HCT116-DLD1 heterofusions were selected in $0.25 \mathrm{mg} / \mathrm{ml}$ of hygromycin plus $1 \mathrm{mg} / \mathrm{ml}$ of G418 for 2 weeks.

\section{Adenovirus infection and cellular analysis}

The generation and purification of recombinant adenoviruses containing $\beta$-galactosidase or $p 53$ genes has been described previously (El-Deiry et al. 1993). To assess $\beta$-galactosidase activity following infection, cells were washed with PBS (phosphate buffered saline), fixed in $0.05 \%$ glutaraldehyde in PBS at $4^{\circ} \mathrm{C}$ for $\overline{5}$ min, then washed with PBS. Cells expressing $\beta$-galactosidase were visualized after incubation at $37^{\circ} \mathrm{C}$ in a 5 -bromo-4-chloro3 -indolyl- $\beta$-D-galactopyranoside. For cell cycle analysis, cells were collected by trypsinization at various times after infection and fixed/stained in $0.6 \%$ NP- $40,3.7 \%$ formaldehyde, $11 \mu \mathrm{g} / \mathrm{ml}$ Hoechst 33258 in PBS. Flow cytometry was then performed as described (Waldman et al. 1995).

\section{Immunoblotting}

Cell extracts were resolved by electrophoresis on a $12 \%$ SDSpolyacrylamide gel (Jule, Inc., New Haven, CT), transferred to Immobilon P membranes (Millipore, Bedford, MA) and probed with either anti-human p53 (clone 1801), or anti-human p21 (clone EA10) monoclonal antibodies, both obtained from Oncogene Science (Cambridge, MA). The PARP-specific monoclonal antibody C2-10 was obtained from Dr. Guy Poirier /Centre de Researche du Chul, Centre Hospitalier de l'Université Laval, Quèbec, Canada), and a bax-specific monoclonal antibody was purchased from Santa Cruz. After incubation with horseradish peroxidase-coupled secondary antibody (Pierce), reactive proteins were visualized with ECL (Amersham, Arlington, Heights, IL).

\section{Acknowledgments}

This work was supported by The Clayton Fund and grants CA57345, CA35494, CA43460, and CA62924. B.V. is an investigator of the Howard Hughes Medical Institute. We thank Jim Flook for expert technical assistance with flow cytometric analysis.

The publication costs of this article were defrayed in part by payment of page charges. This article must therefore be hereby marked "advertisement" in accordance with 18 USC section 1734 solely to indicate this fact.

\section{References}

Baker, S.J., A.C. Preisinger, J.M. Jessup, C. Paraskeva, S. Markowitz, J.K. Willson, S.R. Hamilton, and B. Vogelstein. 1990. p53 gene mutations occur in combination with $17 \mathrm{p}$ allelic deletions as late events in colorectal tumorigenesis. Cancer Res. 50: 7717-7722.

Brugarolas, J., C. Chandrasekaran, J.I. Gordon, D. Beach, T. Jacks, and G.J. Hannon. 1995. Radiation-induced cell cycle arrest compromised by p21 deficiency. Nature 377: 552-557.

Caelles, C., A. Helmberg, and M. Karin. 1994. p53-dependent apoptosis in the absence of transcriptional activation of p53target genes. Nature 370: 220-223.

Canman, C.E., T.M. Gilmer, S.B. Coutts, and M.B. Kastan. 1995. Growth factor modulation of p53-mediated growth arrest versus apoptosis. Genes \& Dev. 9: 600-611.

Casey, G., M. Lo-Hsueh, M.E. Lopez, B. Vogelstein, and E.J. Stanbridge. 1991. Growth suppression of human breast cancer cells by the introduction of a wild-type p53 gene. Oncogene 6: 1791-1797.

Clarke, A.R., C.A. Purdie, D.J. Harrison, R.G. Morris, C.C. Bird, M.L. Hooper, and A.H. Wyllie. 1993. Thymocyte apoptosis induced by p53-dependent and independent pathways. $\mathrm{Na}$ ture 362: 849-852.

Clarke, A.R., S. Gledhill, M.L. Hooper, C.C. Bird, and A.H. Wyllie. 1994. p53 dependence of early apoptotic and proliferative responses within the mouse intestinal epithelium following gamma-irradiation. Oncogene 9: 1767-1773.

Deng, C., P. Zhang, J.W. Harper, S.J. Elledge, and P. Leder. 1995. Mice lacking p21CIP1/WAF1 undergo normal development, but are defective in G1 checkpoint control. Cell 82: 675684.

El-Deiry, W.S., T. Tokino, V.E. Velculescu, D.B. Levy, R. Parsons, J.M. Trent, D. Lin, W.E. Mercer, K.W. Kinzler, and B. Vogelstein. 1993. WAF1, a potential mediator of p53 tumor suppression. Cell 75: 817-825.

El-Deiry, W.S., J.W. Harper, P.M. O'Connor, V.E. Velculescu, C.E. Canman, J. Jackman, J.A. Pietenpol, M. Burrell, D.E. Hill, Y. Wang, K.G. Wilman, W.E. Mercer, M.B. Kastan, K.W. Kohn, S.J. Elledge, K.W. Kinzler, and B. Vogelstein. 1994. WAF1/CIP1 is induced in p53-mediated G1 arrest and apoptosis. Cancer Res. 54: 1169-1174.

Gomez-Manzano, C., J. Fueyo, A.P. Kyritsis, P.A. Steck, J.A. Roth, T.J. McDonnel, K.D. Steck, V.A. Levin, and W.K.A. Yung. 1996. Adenovirus-mediated transfer of the p53 gene produces rapid and generalized death of human glioma cells via apoptosis. Cancer Res. 56: 694-699.

Harper, J.W., G.R. Adami, N. Wei, K. Keyomarsi, and S.J. Elledge. 1993. The p21 Cdk-interacting protein Cipl is a potent inhibitor of G1 cyclin-dependent kinases. Cell 75: 805-816.

Harris, M.P., S. Sutjipto, K.N. Wills, W. Hancock, D.C. Cornell, D.E. Johnson, R.J. Gregory, H.M. Shepard, and D.C. Maneval. 1996. Adenovirus-mediated gene transfer inhibits 
growth of human tumor cells expressing mutant p53 protein. Cancer Gene Ther. 3: 121-130.

Haupt, Y., S. Rowan, E. Shaulian, K.H. Vousden, and M. Oren. 1995. Induction of apoptosis in HeLa cells by trans-activation-deficient p53. Genes \& Dev. 9: 2170-2183.

Hollstein, M., D. Sidransky, B. Vogelstein, and C.C. Harris. 1991. p53 mutations in human cancers. Science 253: 49-53.

Kumar, S. 1995. ICE-like proteases in apoptosis. Trends Biochem. Sci. 20: 198-202.

Lazebnik, Y.A., S.H. Kaufmann, S. Desnoyers, G.G. Poirier, and W.C. Earnshaw. 1994. Cleavage of poly(ADP-ribose) polymerase by a proteinase with properties like ICE. Nature 371: 346-347.

Lin, Y. and S. Benchimol. 1995. Cytokines inhibit p53-mediated apoptosis but not p53-mediated Gl arrest. Mol. Cell. Biol. 15: 6045-6054.

Liu, T.J., A.K. el-Naggar, T.J. McDonnell, K.D. Steck, M. Wang, D.L. Taylor, and G.L. Clayman. 1995. Apoptosis induction mediated by wild-type 53 adenoviral gene transfer in squamous cell carcinoma of the head and neck. Cancer Res. 55: 3117-3122.

Liu, T.J., W.W. Zhang, D.L. Taylor, J.A. Roth, H. Goepfert, and G.L. Clayman. 1994. Growth suppression of human head and neck cancer cells by the introduction of a wild-type p53 gene via a recombinant adenovirus. Cancer Res. 54: 36623667.

Lowe, S.W., E.M. Schmitt, S.W. Smith, B.A. Osborne, and T. Jacks. 1993. p53 is required for radiation-induced apoptosis in mouse thymocytes. Nature 362: 847-849.

Merritt, A.J., C.S. Potten, C.J. Kemp, J.A. Hickman, A. Balmain, D.P. Lane, and P.A. Hall. 1994. The role of p53 in spontaneous and radiation-induced apoptosis in the gastrointestinal tract of normal and p53-deficient mice. Cancer Res. 54: 614 617.

Miyashita, T. and J.C. Reed. 1995. Tumor suppressor p53 is a direct transcriptional activator of the human bax gene. Cell 80: 293-299.

Oltvai, Z.N. and S.J. Korsmeyer. 1994. Checkpoints of dueling dimers foil death wishes. Cell 79: 189-192.

Owen-Schaub, L.B., W. Zhang, I.C. Cusack, L.S. Angelo, S.M. Santee, T. Fujiwara, J.A. Roth, A.B. Deisseroth, W.W. Zhang, E. Kruzel, and R. Radinsky. 1995. Wild-type human p53 and a temperature-sensitive mutant induce Fas/APO-1 expression. Mol. Cell. Biol. 15: 3032-3040.

Poluha, W., D.K. Poluha, B. Chang, N.E. Crosbie, C.M. Schonhoff, D.L. Kilpatrick, and A.H. Ross. 1996. The cyclin-dependent kinase inhibitor p2lWAFl is required for survival of differentiating neuroblastoma cells. Mol. Cell. Biol. 16: 1335-1341.

Sabbatini, P., J. Lin, A.J. Levine, and E. White. 1995. Essential role for p53-mediated transcription in ElA-induced apoptosis. Genes \& Dev. 9: 2184-2192.

Shaw, P., R. Bovey, S. Tardy, R. Sahli, B. Sordat, and J. Costa. 1992. Induction of apoptosis by wild-type p53 in a human colon tumor-derived cell line. Proc. Natl. Acad. Sci. 89: 4495-4499.

Symonds, H., L. Krall, L. Remington, M. Saenz-Robles, S. Lowe, T. Jacks, and T. Van Dyke. 1994. p53-dependent apoptosis suppresses tumor growth and progression in vivo. Cell 78: 703-711.

Takahashi, A. and W.C. Earnshaw. 1996. ICE-related proteases in apoptosis. Curr. Opin. Genet. Dev. 6: 50-55.

Tewari, M., L.T. Quan, K. O'Rouke, S. Desnoyers, Z. Zeng, D.R. Beidler, G.G. Poirier, G.S. Salvesen, and V.M. Dixit. 1995. Yama/CPP32 beta, a mammalian homolog of CED-3, is a
CrmA-inhibitable protease that cleaves the death substrate poly(ADP-ribose) polymerase. Cell 81: 801-809.

Waldman, T., K.W. Kinzler, and B. Vogelstein. 1995. P21 is necessary for the P53-mediated G(1) arrest in human cancer cells. Cancer Res. 55: 5187-5190.

Waldman, T., C. Lengauer, K.W. Kinzler, and B. Vogelstein. 1996. Uncoupling of $S$ phase and mitosis induced by anticancer agents in cells lacking p21. Nature 381: 713-716.

Xiong, Y., G.J. Hannon, H. Zhang, D. Casso, R. Kobayashi, and D. Beach. 1993. p21 is a universal inhibitor of cyclin kinases. Nature 366: 701-704.

Yang, C., C. Cirielli, M.C. Capogrossi, and A. Passaniti. 1995. Adenovinus-mediated wild-type p53 expression induces apoptosis and suppresses tumorigenesis of prostatic tumor cells. Cancer Res. 55: 4210-4213.

Yonish-Rouach, E., D. Resnitzky, J. Lotem, L. Sachs, A. Kimchi, and $M$. Oren. 1991. Wild-type p53 induces apoptosis of myeloid leukaemic cells that is inhibited by interleukin-6. $\mathrm{Na}$ ture 352: 345-347. 


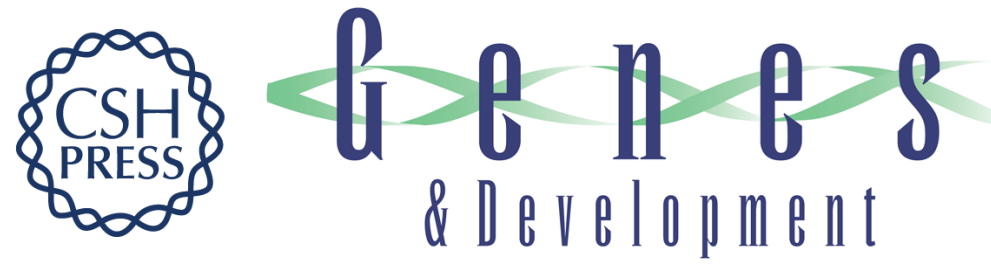

\section{Genetic determinants of p53-induced apoptosis and growth arrest.}

K Polyak, T Waldman, T C He, et al.

Genes Dev. 1996, 10:

Access the most recent version at doi:10.1101/gad.10.15.1945

References This article cites 36 articles, 16 of which can be accessed free at: http://genesdev.cshlp.org/content/10/15/1945.full.html\#ref-list-1

License

Email Alerting

Receive free email alerts when new articles cite this article - sign up in the box at the top Service right corner of the article or click here.

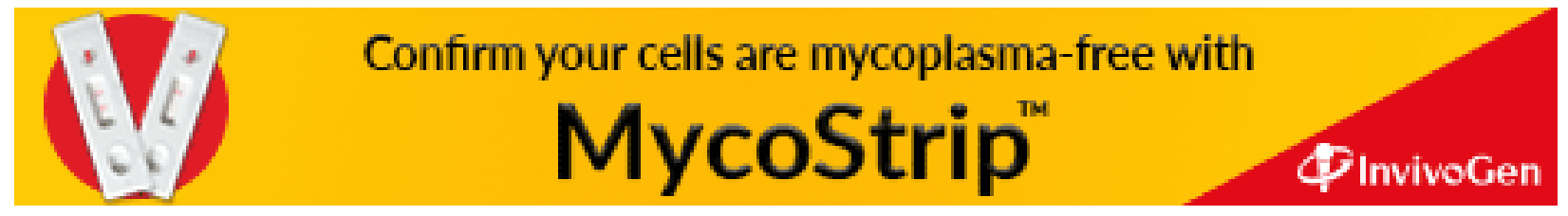

